\title{
Molecular Cloning and Characterization of a Novel Mouse Macrophage C-type Lectin, mMGL2, Which Has a Distinct Carbohydrate Specificity from mMGL1
}

\author{
mMGL1 とは異なる糖特異性を有する新規マウスマクロファージC タイプレクチン、 \\ mMGL2 の分子クローニングと解析
}

\begin{abstract}
Tsuiji, Makoto
Laboratory of Molecular Immunology, The Rockefeller University, 1230 York Avenue, New York, NY 10021, U.S.A. TEL: 212-327-8098, FAX: 212-327-8370, E-mail: tsuijim@ mail.rockefeller.edu
\end{abstract}

Key Words : Galactose-type C-type lectin, Lewis X antigen, Tn antigen, Macrophage, Immature dendritic cell

\begin{abstract}
Protein-carbohydrate interactions serve a variety of functions in the immune system. A number of lectins mediate both pathogen recognition and cell-to-cell interactions using structurally related carbohydrate recognition domains (CRDs).

Macrophage galactose-type C-type lectin (MGL) was previously believed to be derived from a single gene. However, we describe the properties of another novel $\mathrm{M} \varnothing$ galactose-type C-type lectin, mMGL2. As an obvious consequence, the previous mMGL must now be called mMGL1. These lectins are highly homologous to each other except in their cytoplasmic domains and CRDs. The mMGL2 mRNA was also detected in mMGL1positive cells. We found that mMGL2 has distinct carbohydrate specificity from mMGL1. These two lectins may function cooperatively as recognition and endocytic molecules on macrophages and bone marrow-derived immature dendritic cells.
\end{abstract}

要 約

免疫システムにおいて、タンパク質糖鎖相互作用は、様々 な役割を果たしている。数多くのレクチンが、構造的に類似し た糖鎖認識ドメイン (CRD) を利用し、病原体の認識や細胞間相 互作用に関与している。

マクロファージガラクトースタイプ Cタイプレクチン (MGL) は、今まで、一つの遺伝子に由来すると信じられてきた が、私たちは、新規のマクロファージガラクトースタイプCタ イプレクチンである mMGL2 を同定した。今までの mMGL は mMGL1 と命名し直すこととなった。これらのレクチンは、細 胞内ドメインと CRD を除いたドメインにおいて高い相同性を有 しているが、mMGL2 は、mMGL1 とは異なる糖特異性を有して いた。 mMGL2の mRNA は、mMGL1 陽性細胞に検出された。 従って、これらのレクチンは、認識分子およびエンドサイトー シス受容体として、マクロファージおよび骨髄由来未成熟樹状 細胞上で、協調的に機能していると考えられる。

\section{A. Introduction}

Macrophages (MØs) and related cells are widely distributed throughout the body, displaying a morphological and functional diversity. They are found in the lymphoid organs, liver, lungs, gastrointestinal tract, central nervous system, serous cavities, bones, synovia, and skin. Resident MØs mediate clearance of senescent or apoptotic cells, produce and secrete cytokines, are involved in hematopoiesis and bone resorption, transport and present antigens, and regulate neuroendocrine processes. Activated $M \emptyset$ s are recruited to sites of infection, tissue injury, inflammation, and neoplasia and play crucial roles in tissue repair and pathogenesis (1). The distribution and functional heterogeneity of $\mathbf{M Ø s ~ d e r i v e ~ i n ~ p a r t ~ f r o m ~ t h e i r ~ s p e c i a l i z e d ~ p l a s m a ~}$ membrane receptors (2). Cell surface markers such as F4/80, sialoadhesin, $\mathrm{M} \varnothing$ mannose receptor (MMR) and the scavenger receptor (SR-AI/SR-AII) have significantly contributed to the current understanding of $\mathrm{M} \emptyset$ ontogeny and function (3). Yet, in
A. はじめに

マクロファージ (Mø) 扔よび関連細胞は、リンパ組織、肝 臟、肺、消化管、中枢神経系、漿液腔、骨、滑液、皮膚など、 広く体内に分布しており、形態学的にも機能的にも多様性を有 している。常在性 MØは、老化細胞やアポトーシス細胞のクリ アランス、各種のサイトカインの分泌、造血や骨再吸収、抗原 の輸送と提示、神経内分泌系の制御などに関与している。活性 化 MØは、感染、組織障害、新生物の局所に集積し、組織修復 や病態形成に重要な役割を果たしている(1)。MØの分布と機能 の不均一性は、限定した細胞膜受容体に由来する(2)。F4/80、シ アロアドヘシン、MØ マンノース受容体(MMR)、スカベン ジャー受容体 (SR-AI/SR-AII) などの細胞表面マーカーは、MØ の個体発生と機能の理解に大きく貢献してきた(3)。しかし、他 の免疫細胞である $\mathrm{B}$ 細胞や $\mathrm{T}$ 細胞に比較すると、同定されてい 
Trends in Glycoscience and Glycotechnology Vol.15 No.83 (May 2003) pp.153-157

comparison with other immune cells such as B and T lymphocytes, relatively few $\mathrm{M} \varnothing$-restricted cell surface molecules have been identified. The physiological and pathological roles of these putative markers remain unknown.

Protein-carbohydrate interactions serve a variety of functions in the immune system. A number of lectins mediate both pathogen recognition and cell-to-cell interactions using structurally related CRDs. One of the most diversified families of these CRDs is $\mathrm{Ca}^{2+}$-dependent and termed C-type CRDs $(4,5)$. $\mathrm{MØs}$ are known to express several subfamilies of C-type lectins: type 1 multilectin such as MMR, and lectins having type 2 transmembrane configurations such as $\mathrm{M} \varnothing$ galactose-type (previously known as galactose $/ \mathrm{N}$-acetylgalactosamine-specific) C-type lectin (MGL). These lectins seem to mediate carbohydrate-specific endocytosis (6-11). Little is known regarding the expression of selectins, another subfamily of C-type lectins, in MØs.

\section{B. Macrophage Galactose-type C-type Lectin (MGL), an Endocytosis Receptor and/or a Homing Receptor}

MGL was previously cloned from rats, mice, and humans, and characterized. This lectin from mice was shown to have specific affinity for highly-branched $\mathrm{N}$-linked carbohydrate chains with terminal $\beta$-galactosyl groups, and glycopeptides carrying three consecutive $\alpha$-GalNAc-Ser/Thr (Tn-antigen) (12). A human MGL was also shown to have affinity for glycopeptides carrying three consecutive Tn-antigens (13). Surface plasmon resonance revealed that affinity of recombinant hMGL for immobilized glycopeptides increased in parallel with the number of GalNAc residues (14). Tn-antigen was known as a marker of malignant cells and MGL was shown to play a role as a recognition molecule on MØs for tumor cells (15-17). Immunohistochemical localization of mouse MGL (mMGL) with specific monoclonal antibodies revealed that this lectin has a strong association with $\mathrm{M} \varnothing_{\mathrm{s}}$ residing in connective tissue and those infiltrated into tumor tissues (18-20). Recently, mMGL1 was shown to be expressed on the cell surfaces of bone marrowderived immature dendritic cells (21). hMGL is also shown to be expressed on monocyte-derived immature dendritic cells and monocyte-derived immature MØs in humans $(22,23)$. We have shown that mMGL1-positive cells migrate from dermis to regional lymph nodes during the sensitization phase of contact hypersensitivity (24). The migration was initiated by cytokinemediated release of mMGL1-positive cells from the dermis (2426). The cells homed to the boundary of the T-cell area in the regional lymph nodes, and the prevention of migration seemed to interfere with sensitization. This lectin has a role as a receptor for antigens and as an adhesion molecule for homing to suitable regions.

Because we wanted to make clarify the function of MGL in the physiological situation, we were able to produce the $M g l 1$ deficient mice in collaboration with Dr. Stephen M. Hedrick in

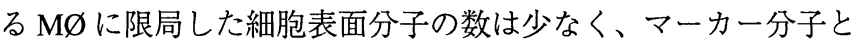
して想定されている分子の生理学的、病態学的な機能について 不明な点が残っている。

免疫システムにおいて、タンパク質糖鎖相互作用は、様々 な役割を果たしている。数多くのレクチンが、構造的に類似し た糖鎖認識ドメイン (CRD) を利用し、病原体の認識や細胞間相 互作用に関与している。これら CRD のうち、もっとも多様性 を有しているファミリーの一つとして、 $\mathrm{Ca}^{2+}$ 依存性であること からC タイプと呼ばれる CRD がある $(4 、 5)$ 。のCタイプレク チンのうち、MMR な゙のI型膜タンパクマルチレクチン、MGL などの II 型膜タンパクレクチンといった、いくつかのサブファ ミリーが、MØに発現していることが知られている。これらレ クチンは糖鎖特異的エンドサイトーシスに関与しているようで ある(6-11)。さらに、MØに発現している他のサブファミリーで あるセレクチンについては、分かっていることが少ない。

B. マクロファージガラクトースタイプCタイプレクチン (MGL) は、 エンドサイトーシス受容体およびホーミング受容体である

MGL は、これまで、ラット、マウス、ヒトから遺伝子ク ローニングされ、解析されてきた。マウス MGL(mMGL) は、末 端に $\beta$-ガラクトースを有する高分岐 $\mathrm{N}$ 結合型糖鎖や、 3 個の連 続した $\alpha$-GalNAc-Ser/Thr (Tn抗原) を有する糖ぺプチドに特異的 に親和性を有していることが示されている(12)。ヒト MGL (hMGL)についても、3 個の連続した Tn 抗原に親和性を有して いる(13)。その親和性は、表面プラズモン共鳴センサー (Biacore system) を用いた解析により、GalNAc の数に比例して増加する ことが明らかになった(14)。Tn 抗原は、腫瘍細胞のマーカーと して知られており、腫瘍細胞の認識に MGL が関与することが 示されている(15-17)。

mMGL に対する特異的抗体を用いたマウス組織の免疫化学 染色により、このレクチンは、全身の結合組織マクロファージ 及び、腫瘍塊に浸潤しているマクロファージに強く発現してい ることが明らかになった(18-20)。最近、mMGL1は、骨䯣由来 未成熟樹状細胞の細胞表面に発現していることが示された (21)。hMGLについても、単球由来未成熟樹状細胞および単球 由来未成熟 MØでの発現が示された(22、23)。接触皮虐炎モデル の抗原感作時に、mMGL1 陽性細胞が、真皮から所属リンパ節 へ移動することが示され(24)、この真皮からの移動には、IL-1 $\alpha$ およびIL-1 $\beta$ などのサイトカインの関与がみられた(24-26)。こ れらの細胞は、所属リンパ節内の $\mathrm{T}$ 細胞領域の境界に現れるこ とが観察され、この移動を阻害すると、感作成立に影響がみら れた。このレクチンは抗原の受容体としてのみならず、適切な 場所に移動するための接着分子としての役割も持っている。

このような、MGLの生理学的機能について、明らかにする ために、Mgll 遺伝子欠損マウスを、Hedrick 博士らとの共同実 
UCSD. Whether mMGL1 is necessary for macrophage function, controlled thymic development, the loss of activated CD8 $\mathrm{T}$ cells, and the turnover of red blood cells was tested. Evidence indicates that mMGL1 may play a non-essential role in several of these macrophage functions (27).

\section{Molecular Cloning and Characterization of a Novel Mouse Macrophage Galactose-Type C-Type Lectin, mMGL2, Which Has a Distinct Carbohydrate Specificity from mMGL1 (28)}

During the step of producing deficient mice, we identified a novel lectin (mMGL2), which has distinct carbohydrate specificity from mMGL1. At first, this lectin was thought to have only one gene, but we found a highly cross-hybridized extra band which was seen in results of southern blot using probe of mMGL1 cDNA. So, we tried to search for homologous fragments from the EST database. A novel mouse macrophage galactose-type C-type lectin 2 (mMGL2) was identified by 5'- and 3'-RACE with cDNA fragments from database of expressed sequence tags.

The sequence of mMGL2 is highly homologous to the mMGL, which should now be called mMGL1. The open reading frame of mMGL2 contains a sequence corresponding to a type II transmembrane protein with 332 amino acids, having a single extracellular C-type lectin domain. The 3' untranslated region included long terminal repeats of mouse early transposon ETn. The Mgl2 gene was cloned from a $129 / \mathrm{SvJ}$ mouse genomic library and sequenced. The gene spans 7,136 base pairs and consists of 10 exons, which is similar to the genomic organization of mMGL1. We identified the BAC clones, which coded the $M g l 2, A s g r l$, and Asgr2 genes. The other clone encodes the $M g l 2$ and $\mathrm{Mgll}$ genes. Therefore, these four C-type lectin genes should be located within about $150 \mathrm{~kb}$ on mouse chromosome 11 .

The RT-PCR analysis indicates that mMGL2 is expressed in cell lines and normal mouse tissues in a macrophage-restricted manner, also very similar to that of mMGL1. The mMgl2 mRNA was also detected in mMGL1-positive cells, which were sorted from thioglycollate-induced peritoneal cells with an mMGL1 specific mAb LOM-8.7. The mMGL1 null mice expressed epitopes reactive with $\mathrm{mAb}$ LOM-14, which is reactive with both mMGL1 and mMGL2, but not with mAb LOM-8.7. These two lectins may function cooperatively as recognition and endocytic molecules on macrophages and related cells.

The soluble recombinant proteins of mMGL2 exhibited carbohydrate specificity for $\alpha \_$or $\beta \_$GalNAc-conjugated soluble polyacrylamides, whereas $\mathrm{mMGL} 1$ preferentially bound $\mathrm{Le}^{\mathrm{x}}$ (Gal $\beta 1-4($ Fuc $\alpha 1-3)$ GlcNAc)-conjugated soluble polyacrylamides in solid phase assays. These antigens were known as tumor-associated polysaccharide antigens or stage specific embryo antigens (SSEAs).
験で作製した。これまでに、MØ機能と、胸腺での細胞分化、 活性化 CD8+ T 細胞の除去、赤血球のターンオーバーにおける mMGL1 の重要性が解析されたが、mMGL1 は必要不可欠なもの ではなかった(27)。

C. mMGL1とは異なる糖特異性を有する新規マウスマクロ ファージガラクトースタイプC タイプレクチン、 mMGL2 の分 子クローニングと解析(28)

遺伝子欠損マウスの作製の過程で、私たちは、MMGL1 とは 異なる糖特異性を有する新規レクチン (mMGL2) を同定した。 始め、このレクチンは 1 つの遺伝子からなると考えられていた が、mMGL1 cDNA をプローブとして行ったサザンブロットの 結果から、強くクロスハイブリダイズするエキストラバンドを 見つけた。そこで、EST データベースから相同性を有する断片 を探し、その断片の5'末端扔よび3’末端 RACE にて全長の mMGL2 を同定した。

mMGL2 の配列は、mMGL1 と高い相同性を有しており、こ の遺伝子には、アミノ酸 332 残基からなり、1つの膜貫通ドメ インを持つ II 型膜タンパク質の open reading frame を有し、3' 末端の非翻訳領域には、マウスの early transposonの long terminal repeat 配列を含んでいた。Mgl2 遺伝子は、129/SvJ マウスゲ ノムライブラリーよりクローニングされ配列決定された。その 結果、Mgl2 遺伝子は、全長 7136 bp であり、10 個のエクソン からなり、構造上 M gll 遺伝子と酷似であった。さらに、BAC クローンについても、Mgl2 遺伝子および、Asgrl 遺伝子と Asgr2 遺伝子を含むものと $M g l l$ 遺伝子と $M g l 2$ 遺伝子を含むものが同 定できた。ゆえに、これらの4つのレクチンは、マウス 11 番 染色体上の約 $150 \mathrm{~kb}$ 以内の領域に存在していることが分かっ た。

各種細胞株と正常マウス組織において、mMGL1 と類似した マクロファージでの mMGL2 の発現が、RT-PCR 解析により確 認された。 mMGL1 特異的抗体 LOM-8.7 の結合性によって、チ オグリコレート誘導腹腔細胞より分画した mMGL1 陽性細胞 に、mMGL2 mRNA が検出された。さらに、mMGL1 欠損マウ スに扔いて、LOM-8.7 抗体は結合しないが、mMGL1 と mMGL2 をともに認識するLOM-14 抗体のエピトープ（おそらく mMGL2）が発現していた。これら 2 つレクチンは、マクロ ファージや関連細胞において協調的に機能していると考えられ る。

固相化アッセイを用いた可溶性リコンビナントタンパク質 の糖結合特異性の解析より、mMGL1 は、ルイス X抗原 (Galß14(Fuco1-3)GlcNAc) が結合している可溶性ポリアクリルアミドに

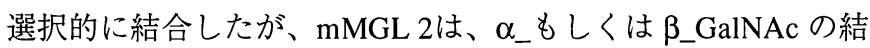
合したポリアクリルアミドに対して特異性を有していた。これ らの抗原は、腫瘍関連抗原およびステージ特異的胎児抗原 (SSEA) として知られているものである。 
Trends in Glycoscience and Glycotechnology Vol.15 No.83 (May 2003) pp.153-157

\section{Conclusions}

We found a novel MØ C-type Lectin, mMGL2, and characterized its genomic structure, expression patterns, and carbohydrate specificity. These lectins are highly homologous to each other except in their cytoplasmic domains and CRDs. mMGL2 has distinct carbohydrate specificity from mMGL1. The BAC clones, which coded the Asgrl, Asgr2, Mgl2, and Mgll genes, were identified. Therefore, these four $\mathrm{C}$-type lectin genes should be located within about $150 \mathrm{~kb}$ on mouse chromosome 11. These lectins seem to be expressed on the same cells at the single cell level and cooperatively functioned to recognize and uptake extracellular molecules. The $\mathrm{Mgl2}$-deficient mice are being prepared. Involvement of coordinated functions of mMGL1 and 2 in such pathogenic processes should be the most important subject of future investigations.

These results indicated that there is another homologous gene in humans. We have tried a search in the genomic database, but we have not identified it. There is another possibility that the recognition systems in mouse and human are different.

\section{E. おわりに}

私たちは、新規マクロファージCタイプレクチン mMGL2 を同定し、そのゲノム構造、発現パターン、糖特異性を解析し た。これらのレクチンは、細胞内ドメインとCRDを除いたドメ インに抒いて、高い相同性を有していた。mMGL2 の糖特異性 は mMGL1 とは異なっていた。Asgrl 遺伝子、Asgr2 遺伝子、 $M g l 2$ 遺伝子、Mgll 遺伝子を含むBACクローンが同定され、こ れらの 4 つのレクチンは、マウス 11 番染色体上の約 $150 \mathrm{~kb}$ 以 内の領域に存在していることが分かった。これらのレクチン は、単一細胞レベルで同一の細胞に発現し、細胞外分子の認識 と取り込みに、協調的に機能していると考えられる。 $M g l 2$ 遺伝 子欠損マウスは現在作成中である。 mMGL1 と mMGL2 の協調 的機能の、病態形成の過程への関与を明らかにすることが、今 後の研究の重大な課題である。

これらの結果は、ヒトにおける他の相同遺伝子の存在を示 唆している。ヒトゲノムデータベースを検索したが、現在のと ころ、同定できていない。他の可能性として、ヒトとマウスで は認識システムが異なるのかもしれない。このことは、免疫シ ステムの進化において興味深い問題点である。

\section{References}

1. Lewis, C., and McGee, J. O. D. (1992) The macrophage: The Natural Immune System, IRL Press at Oxford University Press, Oxford

2. Feizi, T. (2000) Immunol Rev 173, 79-88

3. McKnight, A. J., and Gordon, S. (1998) Adv. Immunol. 68, 271-314

4. Linehan, S. A., Martinez-Pomares, L., and Gordon, S. (2000) Microbes Infect. 2, 279-288

5. Weis, W. I., Taylor, M. E., and Drickamer, K. (1998) Immunol. Rev. 163, 19-34

6. Stahl, P. D., and Ezekowitz, R. A. (1998) Curr. Opin. Immunol. 10, 50-55

7. Liu, Y., Chirino, A. J., Misulovin, Z., Leteux, C., Feizi, T., Nussenzweig, M. C., and Bjorkman, P. J. (2000) J. Exp. Med. 191, 1105-1116

8. Leteux, C., Chai, W., Loveless, R. W., Yuen, C. T., Uhlin-Hansen, L., Combarnous, Y., Jankovic, M., Maric, S. C., Misulovin, Z., Nussenzweig, M. C., and Ten, F. (2000) J. Exp. Med. 191, 1117-1126

9. Ozaki, K., Ii, M., Itoh, N., and Kawasaki, T. (1992) J Biol Chem 267, 9229-9235

10. Kawakami, K., Yamamoto, K., Toyoshima, S., Osawa, T., and Irimura, T. (1994) Jpn. J. Cancer Res. 85, 744-749

11. Valladeau, J., Duvert-Frances, V., Pin, J. J., Kleijmeer, M. J., Ait-Yahia, S., Ravel, O., Vincent, C., Vega, F., Jr., Helms, A., Gorman, D., Zurawski, S. M., Zurawski, G., Ford, J., and Saeland, S. (2001) J. Immunol. 167, 5767-5774

12. Yamamoto, K., Ishida, C., Shinohara, Y., Hasegawa, Y., Konami, Y., Osawa, T., and Irimura, T. (1994) Biochemistry 33, 8159-8166

13. Suzuki, N., Yamamoto, K., Toyoshima, S., Osawa, T., and Irimura, T. (1996) J. Immunol. 156, 128-135

14. Iida, S., Yamamoto, K., and Irimura, T. (1999) J. Biol. Chem. 274, 10697-10705

15. Sakamaki, T., Imai, Y., and Irimura, T. (1995) J. Leukoc. Biol. 57, 407-414

16. Ichii, S., Imai, Y., and Irimura, T. (1997) J. Leukoc. Biol. 62, 761-770

17. Ichii, S., Imai, Y., and Irimura, T. (2000) Cancer Immunol. Immunother. 49, 1-9

18. Imai, Y., Akimoto, Y., Mizuochi, S., Kimura, T., Hirano, H., and Irimura, T. (1995) Immunology 86, 591-598

19. Mizuochi, S., Akimoto, Y., Imai, Y., Hirano, H., and Irimura, T. (1997) Glycobiology 7, 137-146

20. Mizuochi, S., Akimoto, Y., Imai, Y., Hirano, H., and Irimura, T. (1998) Glycoconj. J. 15, 397-404

21. Denda-Nagai, K., Kubota, N., Tsuiji, M., Kamata, M., and Irimura, T. (2002) Glycobiology 12, 443-450

22. Higashi, N., Fujioka, K., Denda-Nagai, K., Hashimoto, S., Nagai, S., Sato, T., Fujita, Y., Morikawa, A., Tsuiji, M., Miyata-Takeuchi, M., Sano, Y., Suzuki, N., Yamamoto, K., Matsushima, K., and Irimura, T. (2002) J. Bio.l Chem. 277, 20686-20693

23. Higashi, N., Morikawa, A., Fujioka, K., Fujita, Y., Sano, Y., Miyata-Takeuchi, M., Suzuki, N., and Irimura, T. (2002) Int. Immunol. 14, 545554

24. Sato, K., Imai, Y., and Irimura, T. (1998) J Immunol. 161, 6835-6844

25. Chun, K., Imai, Y., Higashi, N., and Irimura, T. (2000) J. Leukocyte Biol.68, 471-478

26. Chun, K., Imai, Y., Higashi, N., and Irimura, T. (2000) Int. Immunol. 12, 1695-1703

27. Ommi, T.M., Lin, M.-Y., Page, D.M., Reynolds, S. A., Katayama, C.D., Marth, J.D., Irimura, T., Varki, A., Varki, N., and Hedrick, S. M. (2002) Mol. Cell. Biol. 22, 5173-5181

28. Tsuiji, M., Fujimori, M., Ohashi, Y., Higashi, N., Onami, T. M., Hedrick, S. M., and Irimura, T. (2002) J. Biol. Chem. 277, 28892-28901 


\section{Profile of the Author}

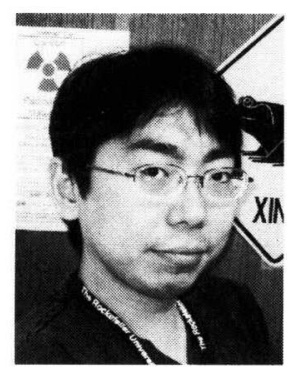

Makoto Tsuiji has been a postdoctral associate (supervised by Professor Michel C. Nussenzweig) at the Laboratory of Molecular Immunology, The Rockefeller University since April, 2003. He graduated from The University of Tokyo in 1994, and received a Ph.D. in Pharmaceutical Sciences, The University of Tokyo in 2003. From 1998, he worked as an assistant professor (supervised by Professor Tatsuro Irimura), The University of Tokyo. His recent scientific interest is the biological roles of C-type lectins in the immune system. 